\title{
West Slavic Language
}

National Cancer Institute

\section{Source}

National Cancer Institute. West Slavic Language. NCI Thesaurus. Code C161859.

A subdivision of the Slavic language group spoken across a continuous region encompassing the Czech Republic, Slovakia, and Poland. 